\title{
Bacterial tricks for turning plants into zombies
}

Microbe deploys proteins that manipulate both the plant it infects and the insects that spread it.

\section{Ed Yong}

08 April 2014

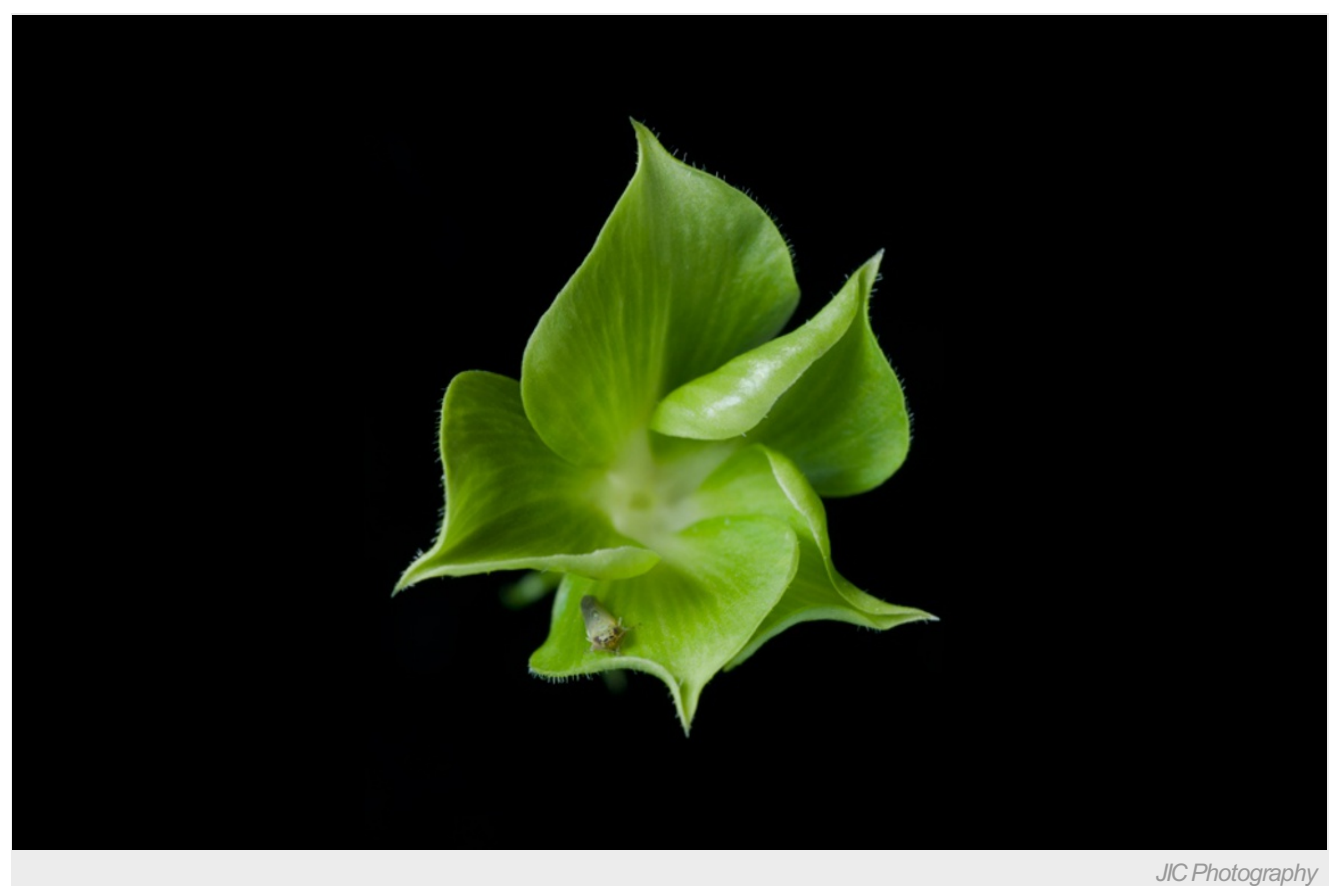

Flowers of Madagascar rosy periwinkle infected by a bacterium produce leaf-like petals and attract a leafhopper that serves as the pathogen's next vector.

Many parasites commandeer the bodies of their hosts in order to spread. Examples of this include horsehair worms that reach water by forcing their cricket hosts to drown themselves, and liver flukes that drive infected ants to climb blades of grass, where cows can eat the insects, and so the flukes.

But parasites can turn plants into zombies, too — and a team of scientists from the John Innes Centre in Norwich, UK, has now discovered how they do it.

When plants are infected by parasitic bacteria called phytoplasmas, their flowers turn into leafy shoots, their petals turn green and they develop a mass of shoots called 'witches' brooms'. This transformation sterilizes the plant, while attracting the sap-sucking insects that carry the bacteria to new hosts.

"The plant appears alive, but it's only there for the good of the pathogen," says plant pathologist Saskia Hogenhout from the John Innes Centre in Norwich, UK. "In an evolutionary sense, the plant is dead and will not produce offspring."

"Many might baulk at the concept of a zombie plant because the idea of plants behaving is strange," says David Hughes, a parasitologist at Pennsylvania State University in University Park. "But they do, and since they do, why wouldn't parasites have evolved to take over their behaviour, as they do for ants and crickets?”

\section{Dual control}

Hogenhout's team had previously shown that the bacteria manipulate their hosts by means of a single protein called SAP54. It interacts with the plant protein RAD23, which sends molecules destined for destruction to the cell's waste-disposal centre - the proteasome. In this case, the targeted molecules are those that make flowers. The findings are published today in PLoS Biology ${ }^{1}$.

The same interaction between SAP54 and these plant proteins increased the plants' attraction for the leafhoppers that transmit phytoplasmas. The team found that leafhoppers lay more eggs on infected plants that had leaf-like flowers than on those with normal 
blooms. They also showed that even SAP54 alone, in the absence of the bacteria, could attract the insects.

"The beauty of the paper is that the bacteria control both plant and insect at the same time with the same protein," said Hughes. "That's stunning."

Hogenhout says that this discovery reveals a connection between a plant's developmental program and its immune system — one that no one had suspected and that probably holds in many other species. She hopes that studying this connection will lead to new ways of simultaneously improving crop production and boosting resistance to pests.

She also wants to work out how other pathogens create zombie plants. The rust fungus Puccinia monoica, for example, sterilizes its hosts and transforms their leaves into bright yellow 'pseudoflowers'. These fake flowers are loaded with fungal cells, and attract insect pollinators that spread the cells to uninfected hosts ${ }^{2}$. No one knows how it reprograms the host, says Hogenhout. "It would be so cool to find out."

Nature | doi:10.1038/nature.2014.15011

\section{References}

1. MacLean, A. M. et al. PLoS Biol. http://dx.doi.org/10.1371/journal.pbio.1001835 (2014).

2. Cano, L. M. et al. PLoS ONE http://dx.doi.org/10.1371/journal.pone.0075293 (2014). 